寄 稿 (Contribution): 膜 (MEMBRANE), 26 (1), 10 (2001)

\title{
21 世紀に期待される膜一反省と展開
}

\author{
明治大学理工学部 仲 川 勤
}

21 世紀の膜を考えるにあたって，簡単に膜の 歴史を眺めてみる。1 831 年の J. V. Mitchell, 1855 年のL' Hermiteの膜透過に関する論文を見 るとき, いわゆる膜の歴史は古い. 膜を材料とし て振りかえる，筆者が大学をでて，最初に与えら れた課題は「包装用プラスチックフィルの化学特 性に関する試験研究」であった。昭和 31 年 (1956) のことである. 当時はポリエチレンフィ ルムが日本でも工業的に製造され, PET (ポリ エチレンテレフタレート) フィルムが米国でやっ と工業的に製造されていた時代である。この時代 は食品等の包装目的にフィルムが使用され，気体 透過性は好まれなかった。 それでも酸素, 窒素, 二酸化炭素の透過係数は異なり「プラスチックフ イルムは呼吸する」といわれていた．高分子膜に よる工業的気体分離の黎明時代であった．種々の 高分子が合成されるようになり，それらの膜化も 容易であることが明らかになってきたが，膜が著 しく脚光を浴びてきたのは，米国で始められた海 水の淡水化計画であろう。高分子膜は逆浸透膜と して研究対象となった. 1969 年米国は初めて月 に人類を送り込む「アポロ計画」に成功した。こ れとほほ同額の金が「海水の淡水化計画」につぎ こまれたといわれる。わが国では 1980 年に通産 省が「次世代基盤技術研究開発制度」を起こした。 当時 3 つの課題が設定された。(1)高効率分離膜, (2)合成金属 (導電性高分子) (3)バイオテクノロジ である。これらは 10 年間継続された. 高効率分 離膜は主に酸素/窒素, 水/アルコールの分離膜 の開発が目的で，主に纎維メーカーの民間企業が 請負い，多額の金が用いられたと思う。正直にい って輝かしい成果があったとはいい難い．各社が 自前の膜にこだわって，新素材への挑戦の熱意が そしかったのではないかと思われる。

その後の大きな政府関連の, 膜が関与したプロ ジェクトは平成 $2 \sim 11$ 年の 10 年間行なわれた (財) 地球環境産業技術研究機構の「接触水素化
反応利用二酸化炭素固定化 - 有効利用技術開発」 (化学的 $\mathrm{CO}_{2}$ 固定化プロジェクト) であろう。こ のプロジェクトは(1) $\mathrm{CO}_{2}$ 分離膜(2)水素化触媒 （膜で分離した $\mathrm{CO}_{2}$ を水素と反応させメタノール とする触媒) (3)水素製造 - 貯蔵 $\left(\mathrm{CO}_{2}\right.$ と反応させ る水素製造のための高効率の電解槽）の開発から 成っていた. $\mathrm{CO}_{2}$ 分離膜の開発には, 主としてカ ルド型のポリイミド膜が用いられ，ある程度の成 果が得られたが，これにも我々にとっては羡まし く思われる巨大な金がつぎ込まれている。この研 究に採用されたポリイミド膜もはじめにカルド型 ありきで，初めから膜素材に制約があったように 思われる。これらはその研究費からみれば, 飛躍 的な分離膜開発に成功とはいい難い. 20 世紀に おける膜開発の反省である.

さて, 21 世紀の膜はこの 20 世紀の膜研究の反 省にたって, 目的に叶った分離膜を新しく合成し, 展開していかなければその将来性はない，時あた かも，高分子合成の分野では「精密重合」法など， その分子量分布のみならず構造が高度に規則的な 高分子の合成が盛んになってきている。「人類の 存亡を賭けた膜開発」といえばおおげさか. 誰し もエネルギー問題，環境保全問題，医療問題を口 にするであろう。これらの問題解決に分離膜が貢 献することは間違いない. 21 世紀の後半までは 予測できないが，まず高効率分離膜は石油にかわ る天然ガスの利用で $\mathrm{CO}_{2} /$ メンの分離膜, 半 導体産業に欠かせない地球温暖化ガス PFC (Perfluoro Compound) の完全分離回収用膜, 河川・湖沼の上水源からのトリハロメタンの分離 除去膜, 単なる分子量分画でなく, 腎臓の機能に 等しい高選択性の血液浄化膜等多くの課題があ る。これらの課題を解決するには, 従来型の研究 体制ではマンネリである，高分子膜なら精密重合 による新素材開発グループを抱え込まなければな らないであろう。 